\title{
Primary production, stocks and fluxes in the Mediterranean seagrass Posidonia oceanica
}

\author{
Gérard Pergent ${ }^{1}$, Javier Romero ${ }^{2}$, Christine Pergent-Martini ${ }^{1}$, \\ Miguel-Angel Mateo ${ }^{2}$, Charles-François Boudouresque ${ }^{3}$ \\ ${ }^{1}$ CEVAREN, Faculté des Sciences et Techniques, Université de Corse, BP 52, F-20250 Corte, France \\ ${ }_{2}^{2}$ Departamento de Ecología, Facultad de Biología, Universidad de Barcelona, Diagonal 645, E-08028 Barcelona, Spain \\ ${ }^{3}$ LBMEB, Faculté des Sciences de Luminy, F-13288 Marseille cedex 9, France
}

\begin{abstract}
Primary production in a Posidonia oceanica seagrass meadow (blades, sheaths and rhizomes) was estimated at 3 sites in Lacco Ameno Bay (Ischia, Italy). Foliar primary production ranged from 51 to $142 \mathrm{~g}$ dry $w t \mathrm{~m}^{2} \mathrm{yr}^{-1}$ for sheaths and 167 to $530 \mathrm{~g}$ dry $w \mathrm{t} \mathrm{m}^{2} \mathrm{yr}^{-1}$ for blades. Rhizome production ranged from 20 to $42 \mathrm{~g} \mathrm{dry} \mathrm{wt} \mathrm{m}^{2} \mathrm{yr}^{-1}$. The largest part of primary production was degraded in situ in the litter ( $42 \%)$; the remainder was either exported to other ecosystems (29\%) or buried in the matte $(29 \%)$. The loss of matter due to burial of sheaths and rhizomes in the matte, a phenomenon that is unique to Posidonia oceanica meadows, is considerable.
\end{abstract}

KEY WORDS: Seagrass - Posidonia oceanica Primary production · Litter

\section{INTRODUCTION}

The seagrass Posidonia oceanica (Linnaeus) Delile is, with Thalassia testudinum Banks ex König, Zostera marina Linnaeus and several Australian seagrasses, one of the most productive marine phanerogams (Parker et al. 1963, Greenway 1974, Sand Jensen 1975 , McRoy \& McMillan 1977, Nienhuis \& De Bree 1980, Hillman et al. 1989). Leaf production, measured by various techniques (Oxygen, carbon-14, leaf marking, lepidochronology) ranges from 300 to $2000 \mathrm{~g}$ dry weight $\mathrm{m}^{-2} \mathrm{yr}^{-1}$ (Bay 1984, Thelin \& Giorgi 1984, Libes 1985, Romero 1989, Pergent \& Pergent-Martini 1991). As in most marine phanerogam-based ecosystems, only a small amount of the leaf production is consumed on the plant by macro-invertebrates (echinoderms, crustaceans) and fishes; most of the consumption of leaves occurs through the action of crustaceans, gastropods and microorganisms in the litter (Fenchel 1970, 1977, Wittmann et al. 1981). The flux of matter from primary production follows mainly 1 of 2 pathways: (1) When the leaves fall, the blade becomes detached from the plant and contributes to the litter, where decomposition occurs (Peres 1953, Picard 1965, Fenchel
1977. Francour 1990, Pergent-Martini et al. 1990, Romero et al. 1992). (2) The sheathing base of the leaf remains attached to the rhizome within the matte where the process of decay is very slow (Molinier \& Picard 1952, Boudouresque 1986, Pergent 1990, Romero et al. 1992).

The primary production that goes into the litter either remains within the meadow, where it undergoes a kinetic process of rapid decay that can be accurately estimated (Pergent-Martini et al. 1990, Romero et al. 1992), or is exported to other ecosystems where it may represent a trophic input of considerable importance (Peres 1953, Picard 1965, Fenchel 1977). For example, the gut of the sea-urchin Paracentrotus lividus Lamarck in algae-dominated communities distant from Posidonia oceanica meadows can contain as much as $31 \%$ of Posidonia oceanica leaves (Verlaque \& Nedelec 1983)

The primary production that is buried in the matte (sheaths and rhizomes) decays very slowly (Francour 1985, Pergent-Martini et al. 1990, Romero et al. 1992). The sheaths and rhizomes are in fact highly resistant to putrefaction, and may persist for thousands of years within the matte (Boudouresque et al. 1980). The con- 
struction of a matte (living and dead rhizomes and roots, with the interstices filled with sediment) is one of the unique characteristics of Posidonia oceanica meadows (Pergent 1990).

In the present study, we attempted to quantify the flux of matter (dry weight) and of mineral elements $(\mathrm{C}, \mathrm{N}, \mathrm{P}$ ) originating in the leaf primary production of Posidonia oceanica and to follow their distribution and dynamics both within and outside of the ecosystem, by analysing (1) consumption in situ, (2) litter degraded within the meadow, (3) litter exported to other ecosystems, and (4) stocking within the matte

\section{MATERIAL AND METHODS}

Sampling sites. Samples were taken around the Island of Ischia (Gulf of Naples, Italy) within the Posidonia oceanica meadow of Lacco Ameno (Colantoni et al. 1982, Mazzella et al. 1989) at 3 sites (Fig. 1): LA05 (4 to $6 \mathrm{~m}$ depth), LA10 (10 to $12 \mathrm{~m}$ ), and LA20 (20 to $22 \mathrm{~m}$ ).

Estimation of primary production, using lepidochronological data. Twenty orthotropic rhizomes were collected at random by scuba diving ( 80 to $90 \%$ of rhizomes are orthotropic in this meadow), every month between July 1988 and July 1990, at the 3 sites. Meadow density (number of shoots per square meter) was estimated in situ using a $35 \times 35 \mathrm{~cm}$ quadrat. In all, 21 measurements were taken for each site (meadow density is constant throughout the year for Posidonia oceanica).

For each rhizome, the sheaths were carefully detached and numbered starting from the older (near the base) to the more recent ones (near the living leaves). The length of each sheath was carefully mea- sured and a thin cross section was made between 10 and $12 \mathrm{~mm}$ above the base of the sheath. Its thickness at the centre was measured under a microscope (Pergent 1990). These sheaths show cyclic variations in their thickness, each cycle corresponding to a $1 \mathrm{yr}$ period. The study of these chronological cycles is termed lepidochronology (Pergent 1990).

Primary production was estimated following Pergent \& Pergent-Martini (1991), on the basis of 3 parameters:

(1) Number of leaves produced annually. This parameter could be determined for the study period from the leaf renewal cycle estimated from lepidochronological data, and for previous years from the mean number of scales per cycle (Pergent 1990, Pergent \& Pergent-Martini 1990)

(2) Leaf length. This corresponds to the mean length of the oldest blades and sheaths, determined for each month between July 1988 and July 1990. Only entire leaves (still possessing their apex) were taken into account (Pergent \& Pergent-Martini 1991).

(3) Leaf density, i.e. leaf weight by unit of length (Sand-Jensen 1975). In the present study, the parameter taken into consideration was final density, just before shedding.

We also measured length, dry weight (dw), and $C$ and $\mathrm{N}$ contents (Micro CHN Determinator, CHN 800) of the rhizome segments, determined between each pair of sheaths of minimum thickness, corresponding to a 1 yr period.

Number and biometry of living leaves (foliar shoots) were determined using the technique of Giraud (1979). Coefficient $A$ (percentage of leaves which have lost their apex) was also noted. Constant dry weight $\left(70^{\circ} \mathrm{C}\right)$ and $\mathrm{C}$ and $\mathrm{N}$ contents of the oldest leaf from each shoot were measured (calcareous epiphytes were previously removed by scraping with a razor blade).

Estimation of litter stocks. Samples were taken using a suction device inside a $35 \times 35 \mathrm{~cm}$ quadrat every 3 mo (July and October 1988, January, April and July 1989) at LA05, LA 10 and LA20 with 3 replicates in each case. The samples included all the material lying on the sediment, and the sediment itself, to a depth of 5 to $10 \mathrm{~cm}$. The samples were sorted immediately, after thorough washing with running seawater, into 3 fractions according to Romero et al. (1992): (1) coarse leaf litter $(>0.8 \mathrm{~cm}),(2)$ fine leaf litter (between 0.1 and $0.8 \mathrm{~cm}$ ), (3) material from the belowground parts (dead rhizomes, roots and leaf base sheaths). These fractions were
Fig. 1 Ischia island, Italy, showing the location of the study area. Location of Posidonia oceanica meadow shown according to Colantoni et al. (1982) 
dried at $70^{\circ} \mathrm{C}$ until reaching a constant weight, then weighed separately.

Decay experiments. Classic litter bag experiments were performed at sites LA05 and LA20 (Bocock et al. 1960, Godshalk \& Wetzel 1978, Brock et al. 1985 Josselyn et al. 1986). A known amount (30 $\mathrm{g}$ fresh wt) of senescent leaves Posidonia oceanica was enclosed in a series of mesh bags (mesh size $=0.1 \mathrm{~cm}$ ). The bags were then placed in the meadow and collected at increasing time intervals. At each sampling, 3 bags were collected at random and taken to the laboratory. There the samples were washed, the fauna was removed and the litter then sorted into 2 fractions (coarse leaf litter and fine leaf litter). These fractions were weighed separately after drying at $70^{\circ} \mathrm{C}$ to constant weight.

Belowground parts. Samples of rhizomes and roots were taken using a diver-held corer (Pirc 1983) at LA05 and LA20, penetrating to around $20 \mathrm{~cm}$ depth in the sediment. The samples were washed carefully, divided into 3 vertical sections and sorted into the following fractions: (1) living rhizomes, (2) dead rhizomes and remaining leaf sheaths, (3) living roots, (4) dead roots and (5) fine undifferentiated fraction (between 0.1 and $0.8 \mathrm{~cm}$ ), the fractions were then weighed as described above. The criteria used in the fractioning of the belowground parts of the plant were those described in Francour \& Semroud (1992).

Lepidochronological analysis was used to establish the exact year of formation of a given rhizome section or a given leaf base, and consequently the decay rate of the associated tissues (Pergent 1990, Pergent \& Pergent-Martini 1990).

Chemical elementary composition. In order to assess the turnover of various biogenic elements in the different compartments, the elementary composition (carbon, nitrogen and phosphorus) was determined for subsamples, dried at $\max .70^{\circ} \mathrm{C}$, of the following items:
(1) litter from LA05 and LA20, (2) material from the decay experiments (LA05 and LA20), and (3) belowground parts (sheaths and rhizomes)

The subsamples were ground to a fine powder to determine $\mathrm{C}$ and $\mathrm{N}$ content. $\mathrm{P}$ content was analysed using ICP (Induction Coupling Plasma) after wet acid digestion following Delgado (1986), adapted to a microwave digestor as described by Mateo \& Sabate (1989).

\section{RESULTS}

\section{Leaf primary production}

The mean number of leaves produced per shoot during a 1 yr period (average between data from July 1988 to July 1989 and from July 1989 to July 1990) ranged from 6.6 to 7.7 (Table 1).

Leaf density depends on the width and thickness of leaves, and varies according to age and season of formation (Bedhomme et al. 1983, Thelin \& Giorgi 1984). It ranged from 7.7 to $9.9 \mathrm{mg} \mathrm{dw} \mathrm{cm}^{-1}$ for sheaths and from

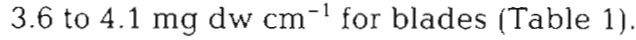

Annual mean length for the oldest adult leaves ranged from 32.0 to $39.4 \mathrm{~cm}$ (Table 1).

Mean net production of leaves ranged from 0.86 to $1.42 \mathrm{~g} \mathrm{dw}$ shoot ${ }^{-1} \mathrm{yr}^{-1}$, depending on depth (Table 1); of this production, 21 to $23 \%$ was in the sheaths and 77 to $79 \%$ in the blades. Meadow density (from $253 \pm 23$ to $473 \pm 44$ shoots $\mathrm{m}^{-2}$ ) was used to evaluate net primary production of the meadow in each site (Table 1); it ranged from 218 to $672 \mathrm{~g} \mathrm{dw} \mathrm{m}^{-2} \mathrm{yr}^{-1}$.

The mean proportion of carbon in the Posidonia oceanica leaves, measured at the 3 sites with a Micro CHN Determinator, was $27.4 \pm 1.5 \%$ of dry weight (Pergent \& Pergent-Martini 1991); the mean net primary production of leaves was 184,128 and $60 \mathrm{~g} \mathrm{C} \mathrm{m}^{-2}$ $\mathrm{yr}^{-1}$ at 5,10 and $20 \mathrm{~m}$ depth, respectively (Fig. 2).

Table 1. Posidonia oceanica. Net foliar primary production (per shoot and per $\mathrm{m}^{2}$ ) during a 1 yr period (average between July 1988 to July 1989 and July 1989 to July 1990), 3 sites at Lacco Ameno (Ischia, Italy)

\begin{tabular}{|c|c|c|c|c|c|c|c|}
\hline \multirow{2}{*}{$\begin{array}{l}\text { Depth } \\
\text { (m) }\end{array}$} & \multirow{2}{*}{$\begin{array}{l}\text { Leaf } \\
\text { section }\end{array}$} & \multirow{2}{*}{$\begin{array}{c}\text { No. } \\
\text { of leaves } \\
\mathrm{yr}^{-1}\end{array}$} & \multirow{2}{*}{$\begin{array}{c}\text { Leaf } \\
\text { density } \\
\left.\text { (mg dw } \mathrm{cm}^{-1}\right)\end{array}$} & \multirow{2}{*}{$\begin{array}{l}\text { Mean leaf } \\
\text { length } \\
\text { (mm) }\end{array}$} & \multirow{2}{*}{$\begin{array}{c}\text { Meadow } \\
\text { density } \\
\left(\mathrm{m}^{2}\right)\end{array}$} & \multicolumn{2}{|c|}{ Leaf primary production } \\
\hline & & & & & & $g d w$ shoot ${ }^{-1} y^{-1}$ & $g d w m^{-2} y^{-1}$ \\
\hline \multirow[t]{3}{*}{5} & Sheath & 7.65 & 9.9 & 39 & 473 & 0.30 & 142 \\
\hline & Blade & 7.65 & 4.1 & 355 & 473 & 1.12 & 530 \\
\hline & Total & & & 394 & & 1.42 & 672 \\
\hline \multirow[t]{3}{*}{10} & Sheath & 7.55 & 9.0 & 41 & 351 & 0.29 & 102 \\
\hline & Blade & 7.55 & 3.9 & 349 & 351 & 1.04 & 365 \\
\hline & Total & & & 391 & & 1.33 & 467 \\
\hline \multirow[t]{3}{*}{20} & Sheath & 6.55 & 7.7 & 40 & 253 & 0.20 & 51 \\
\hline & Blade & 6.55 & 3.6 & 281 & 253 & 0.66 & 167 \\
\hline & Total & & & 320 & & 0.86 & 218 \\
\hline
\end{tabular}




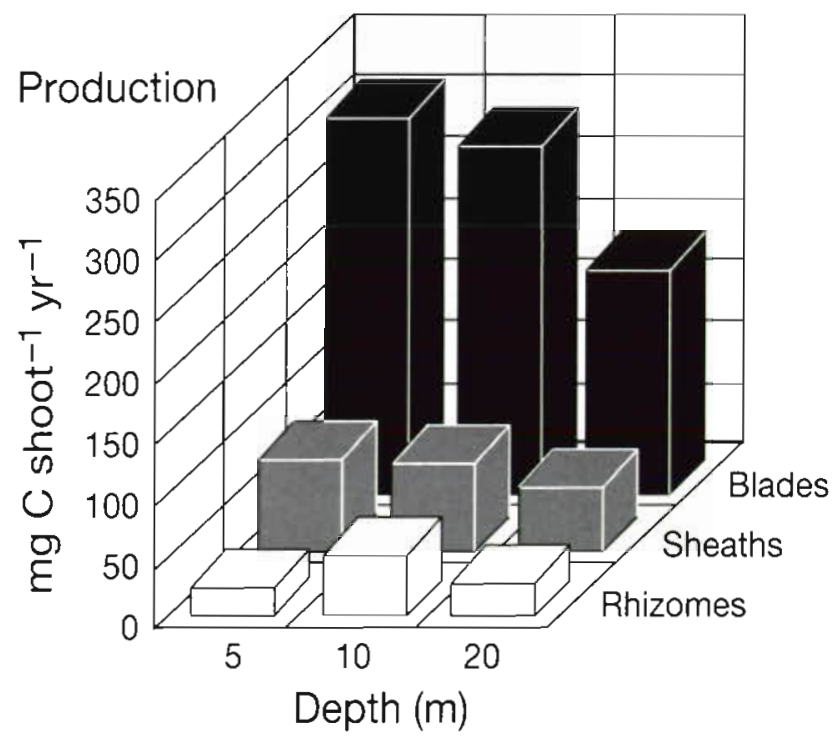

Fig. 2. Posidonia oceanica. Net primary production by depth around Ischia island, Italy

\section{Rhizome production}

Net rhizome production was low but not insignificant in comparison with leaf production: $0.08,0.12$ and $0.08 \mathrm{~g} \mathrm{dw}$ shoot ${ }^{-1} \mathrm{yr}^{-1}$ at 5, 10 and $20 \mathrm{~m}$ depth, respectively, or 37.8, 42.1 and $20.2 \mathrm{~g} \mathrm{dw} \mathrm{m}^{-2} \mathrm{yr}^{-1}$ (between 6 and $9 \%$ of total production).

The mean percentage of carbon in segments of rhizomes that had appeared during the $2 \mathrm{yr}$ of our study at Ischia was $34.8 \pm 0.44 \%$; mean rhizome production of the meadow (in $\mathrm{g} \mathrm{C} \mathrm{m}^{-2} \mathrm{yr}^{-1}$ ) was, between July 1988 and July 1990, 13.0 at LA05, 14.7 at LA10 and 7.1 at LA20 (Fig. 2).

Table 2. Coefficient A for Posidonia oceanica leaves (\%) in the Mediterranean (values are annual averages) . Ad. = adult leaves; Int. $=$ intermediate leaves

\begin{tabular}{|lcrrrl|}
\hline Locality & $\begin{array}{c}\text { Mean } \\
\text { depth }(\mathrm{m})\end{array}$ & Ad. & Int. & $\begin{array}{c}\text { Average } \\
\text { (Ad. and Int.) }\end{array}$ & Source \\
\hline Algiers Bay & 2 & 99.3 & 44.7 & 73.5 & Semroud et al. (1990) \\
(Algeria) & 8 & 93.9 & 30.6 & 63.7 & \\
Urla-Iskele & 2 & 74.0 & 11.2 & 48.1 & Pergent \& \\
(Turkey) & 5 & 77.4 & 12.0 & 50.1 & Pergent-Martini (1988) \\
Port-Cros & 2 & 64.6 & 27.0 & 51.2 & Pergent \& \\
(France) & 11 & 27.5 & 3.8 & 19.2 & Pergent-Martini (1988) \\
& 23 & 27.2 & 0.8 & 19.0 & \\
Banyuls- & 2 & 94.9 & 41.7 & 79.4 & Pergent \& \\
sur-Mer & 12 & 56.8 & 14.4 & 44.4 & Pergent-Martini (1988) \\
(France) & 19 & 44.2 & 9.1 & 34.3 & \\
Ischia & 5 & 43.1 & 5.9 & 30.9 & Present study \\
(Italy) & 10 & 24.8 & 2.8 & 19.3 & \\
& 20 & 24.8 & 2.0 & 18.9 & \\
\hline
\end{tabular}

\section{Consumption in situ}

Predation pressure from grazers was estimated using Coefficient $A$; it would appear that around the Island of Ischia, consumption of leaves on living plants is low (Table 2)

\section{Primary production contributing to the litter and kinetics of decay}

We assumed that consumption of living leaves was insignificant (see 'Discussion'). Consequently, the amount of primary production contributing to the litter corresponds to that of the leaf blade; this is in fact the only part of the leaf that becomes detached, since the sheath remains attached to the rhizome. This material flux ranged from 46 (20 $\mathrm{m}$ depth) to 145 (5 $\mathrm{m}$ depth) $\mathrm{gC} \mathrm{m} \mathrm{yr}^{-1}$

The decay kinetics of Posidonia oceanica leaf blades, estimated on the basis of decay experiments (litter bags), followed a simple negative exponential model, with a high goodness of fit (Romero et al. 1992; Fig. 3). Weight loss was more rapid at $5 \mathrm{~m}$ than at $20 \mathrm{~m}$ depth for equivalent periods. The decay rate of $k$ (exponent of the model) was around $-0.0062 \mathrm{~d}^{-1}$ for LA05 and $-0.0033 \mathrm{~d}^{-1}$ for LA20 (decay experiment between October and April).

\section{Primary production stocked in the matte and kinetics of decay}

The primary production that is stocked in the matte (belowground) corresponds to (1) the sheath bases of the leaves which remain attached to the rhizome, and (2) the rhizomes themselves. This represents a major part of the primary production, between 21 and $52 \mathrm{~g}$ of $\mathrm{C}$ $\mathrm{m}^{-2} \mathrm{yr}^{-1}$, or an average of $29 \%$ of the total net primary production (Table 3).

The decay kinetics of the sheaths and rhizomes within the matte were estimated by means of lepidochronological data. Sheath decay was low; from these data, and again assuming a simple exponential model, a decay rate of $k=$ $-0.216 \mathrm{yr}^{-1}$ at $5 \mathrm{~m}$ and $-0.110 \mathrm{yr}^{-1}$ at $20 \mathrm{~m}$ depth could be computed. Similarly, a model of rhizome decay was established but no weight loss was evident. This observation 


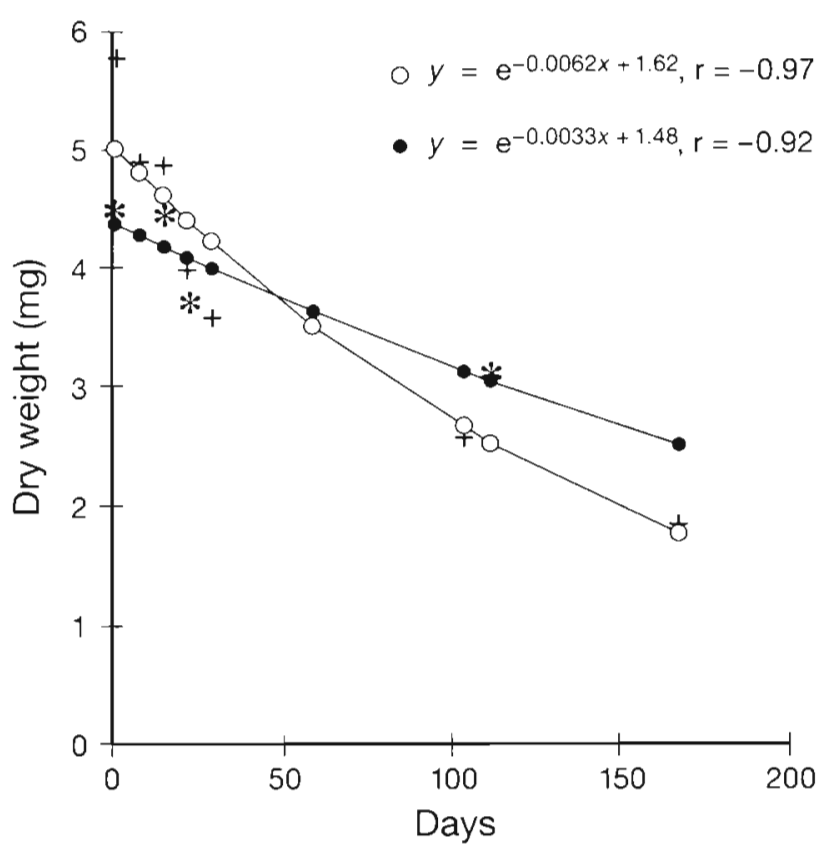

Fig. 3. Posidonia oceanica. Decay kinetics of leaves at Ischia, at $5 \mathrm{~m} \mathrm{(+)}$ and $20 \mathrm{~m}(*)$ depth

is probably due to the fact that rhizomes remain alive for several years (Francour 1985)

Changes in $\mathrm{C}, \mathrm{N}$ and $\mathrm{P}$ content of the belowground parts were analysed. There was a slight carbon loss with time in sheaths (principically at Sites LA05 and LA20; $\mathrm{r}=0.85$ and 0.84), while $\mathrm{N}$ and $\mathrm{P}$ content decreased sharply in the rhizomes but remained constant $(\mathrm{N})$ or increased $(\mathrm{P})$ in sheaths (Table 4 ).

\section{DISCUSSION}

Coefficient A (Giraud 1979) is purely descriptive and can only be considered an overall estimation. Loss of the apex may in fact be due either to consumption in situ of part of the plant by a grazer, or to hydrodynamic action, especially in shallow sites. Coefficient $A$ is therefore insufficient to allow quantitative estimation of this trophic flux and can, at best, serve for comparison between localities or between

Table 3. Estimation and distribution of Posidonia oceanica net primary production around Ischia island

\begin{tabular}{|lrrrrrr|}
\hline \multirow{2}{*}{ Site } & \multicolumn{3}{c}{ Production $\left(\mathrm{g} \mathrm{C} \mathrm{m}^{-2} \mathrm{yr}^{-1}\right)$} & \multicolumn{3}{c|}{ Flux $\left(\mathrm{g} \mathrm{C} \mathrm{m}^{-2} \mathrm{yr}^{-1}\right)$} \\
& Sites & Blade & Sheath & Exportation & Decay & Matte \\
& & & & 50.8 & 94.3 & 52.1 \\
LA05 & 145.1 & 38.9 & 13.2 & 49.0 & 51.0 & 42.6 \\
LA10 & 100.0 & 27.9 & 14.7 & 16.9 & 28.8 & 20.9 \\
LA20 & 45.7 & 13.9 & 7.0 & & & \\
\end{tabular}

depths. The low $A$ value recorded in the Lacco Ameno meadow, compared with other Mediterranean sites, would appear to suggest that this flux is particularly weak at Ischia (Table 2). This finding is no doubt related to the fact that, in this meadow, we observed very small numbers of macro-grazers, which are generally responsible for most of this consumption in situ le.g. Sarpa salpa Linnaeus (Harmelin-Vivien \& Francour 1992), Paracentrotus lividus (Bulteel et al. 1992)]. In addition, it would appear that most of this material flux is returned to the litter after passing through the digestive system of the grazers, and that it is mostly the leaf epiphyte which are assimilated, at least for S. salpa (Dauby \& Coulon 1993). It may thus be suggested that the main result of grazer action is the mechanical fragmentation of the leaves, which favours the action of detritus feeders in the litter. This phenomenon has also been noted by other investigators for other phanerogam species (Ogden 1980, Thayer et al. 1984). In fact, the seagrass grazers apparently are not efficient digesters and typically absorb less than $50 \%$ of the ingested material (Thayer et al. 1984). Also, in some cases, this recycling may be functionally more important in transferring nutrients to adjacent ecosystems than in supplying nutrients to the seagrass ecosystem; defecation may not occur in the feeding area but rather in the area where the animal rests (Ogden 1980).

Nevertheless, even if direct consumption of marine phanerogam leaves by grazers appears to be generally slight (McRoy 1966, Mann 1972, Greenway 1976, Ott \& Maurer 1977. Hemminga et al. 1991), this material flux varies considerably according to the species in question, the site and particularly grazer density (Greenway 1976, Ott 1981). Even in Thalassia testudinum, where direct consumption by grazers (e.g. sea urchins) appears to be particularly high for a marine phanerogam (Ott 1981), blade consumption by grazing ranges from between 5 and 10\% (Zieman et al. 1979) to $50 \%$ (overgrazing by echinoids; Greenway 1976). In Posidonia australis, $3 \%$ of leaf consumption (in carbon) is by grazers, whereas in P. oceanica, Ott \& Maurer (1977) suggest a value of $4 \%$ of standing stock (or $9 \%$ of net production).

The part of the primary production entering the litter appeared to be the largest, ranging from 69 to $74 \%$ of total annual production (in carbon). The litter stock fluctuates over the year according to input (e.g. leaf fall) and output (export and decay). On the basis of (1) the bathymetric distribution of litter, (2) inputs of new litter, i.e. shedding of leaf blades, in the meadow (from primary production of blades), and (3) the 
Table 4. Posidonia oceanica. Decay kinetics of sheaths and rhizomes ( $C, N$, and $P$ content) in the matte

\begin{tabular}{|c|c|c|c|c|c|c|}
\hline \multirow{2}{*}{$\begin{array}{l}\text { Site } \\
\quad \text { Year }\end{array}$} & \multicolumn{3}{|c|}{ Sheaths } & \multicolumn{3}{|c|}{ Rhizomes } \\
\hline & $\% \mathrm{C}$ & $\% N$ & $\% \mathrm{P}$ & $\% C$ & $\% \mathrm{~N}$ & $\% P$ \\
\hline \multicolumn{7}{|l|}{ LA05 } \\
\hline 1989 & 36.6 & 0.31 & 0.017 & & & \\
\hline 1988 & 34.4 & 0.36 & 0.016 & 42.1 & 3.79 & 0.26 \\
\hline 1987 & 33.1 & 0.33 & 0.019 & 42.2 & 2.06 & 0.14 \\
\hline 1986 & 34.3 & 0.35 & 0.015 & 41.6 & 1.63 & 0.11 \\
\hline 1985 & 32.1 & 0.48 & 0.026 & 42.3 & 0.76 & \\
\hline \multicolumn{7}{|l|}{ LA10 } \\
\hline 1989 & 36.0 & 0.39 & & & & \\
\hline 1988 & 36.3 & 0.52 & 0.019 & 42.7 & 3.92 & 0.063 \\
\hline 1987 & 35.9 & 0.34 & 0.018 & 43.0 & 3.43 & 0.040 \\
\hline 1986 & 36.9 & 0.41 & 0.022 & 43.7 & 2.04 & 0.030 \\
\hline 1985 & 37.7 & 0.36 & 0.021 & 43.3 & 1.36 & 0.031 \\
\hline 1984 & 35.2 & 0.41 & 0.025 & 42.5 & 0.56 & 0.028 \\
\hline 1983 & 36.2 & 0.35 & 0.123 & & & 0.029 \\
\hline 1982 & 35.4 & 0.43 & 0.026 & 42.3 & 0.94 & \\
\hline \multicolumn{7}{|l|}{ LA20 } \\
\hline 1989 & 31.2 & 0.35 & 0.014 & & & \\
\hline 1988 & 32.0 & 0.34 & 0.016 & 40.5 & 3.80 & 0.094 \\
\hline 1987 & 31.1 & 0.37 & 0.021 & 41.2 & 3.68 & \\
\hline 1986 & 30.1 & 0.31 & 0.012 & 41.0 & 2.06 & \\
\hline 1985 & 30.5 & 0.34 & 0.027 & 42.2 & 0.99 & 0.039 \\
\hline 1984 & 30.4 & 0.39 & 0.026 & 41.2 & 0.89 & 0.043 \\
\hline 1983 & 29.8 & 0.37 & 0.022 & 40.6 & 0.89 & 0.031 \\
\hline 1982 & 30.6 & 0.42 & 0.036 & 42.4 & 0.63 & 0.035 \\
\hline 1981 & 29.4 & 0.29 & 0.028 & 41.9 & 2.69 & 0.030 \\
\hline 1980 & 29.2 & 0.39 & 0.030 & 40.8 & 0.56 & 0.030 \\
\hline
\end{tabular}

decay rate of leaf litter in situ (from decay experiments), Romero et al. (1992) established a simplified model for deducing the amount of litter exported out of the ecosystem. They estimated it to be, on average, $50 \%$ for the whole meadow between 1 and $32 \mathrm{~m}$ depth, with wide variations according to depth. Using this model with our own primary production data, for the 3 stations studied, we estimate the exportation rate (in carbon) to be 35,49 and $37 \%$ of litter (or 26,34 and $25 \%$ of total primary production), at 5,10 and $20 \mathrm{~m}$ depth, respectively (Table 3 ). These values are similar to those reported by Francour (1990) at Port-Cros (Var, France) between 3 and $11 \mathrm{~m}$ depth (40\% exported on average), and by Ott (1980) at Ischia (3 to $6 \mathrm{~m}$ depth), who estimated that $55 \%$ of blade production was exported.

For other seagrasses, Hemminga et al. (1991) demonstrated that the exportation rate may vary widely according to the station studied (1 to $30 \%$ for Zostera marina: in Josselyn et al. 1983, Bach et al. 1986), or the species $11 \%$ for Thalassia testudinum: Zieman et al. $1979 ; 27$ to $79 \%$ for Syringodium filiforme: Fry \& Virnstein 1988).

The relative stability of the values recorded for Posidonia oceanica (between 35 and $55 \%$ exported) may be explained, on the one hand, by the similarity of the sites studied (Ischia and Port-Cros), in particular with regard to bathymetry and hydrodynamism, and on the other by the fact that the measurements were carried out in meadows situated at relatively great depth ( 3 to $20 \mathrm{~m}$ ) and therefore less exposed to hydrodynamic variations than shallow water meadows.

There is little recycling of the primary production that is buried in the matte (sheaths and rhizomes), and most of this production is lost to the ecosystem $(29 \%$ of the net primary production). In contrast to aboveground primary production, where the turnover time is low (on the order of months), for the belowground part the turnover time is much longer (from years to centuries). Our data would appear to indicate that the Posidonia oceanica ecosystem acts as a sink for the various biogenic elements.

\section{CONCLUSION}

With the exception of the part of primary production that is consumed in situ, but which contributes for the most part to the litter (faeces), we have quantified the various fluxes derived from primary production (Fig. 4). It appears that most of the primary production (in carbon) decays in situ $(42 \%)$, while the remainder is distributed more or less equally between export $(29 \%)$ and burial in the matte $(29 \%)$. The main process by which the primary production in the Posidonia oceanica community is used is consumption by detritusfeeders.

Both immobilization (in the matte) and export represent net losses of biogenic elements for the system. The loss of matter due to burial of sheaths and rhizomes in the matte, a phenomenon that is unique to Posidonia meadows, is considerable.

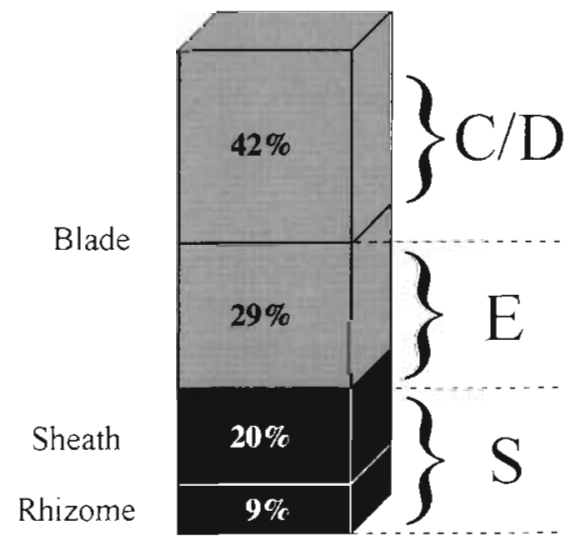

Fig. 4. Posidonia oceanica. Fluxes derived from the primary production: $\mathrm{C} / \mathrm{D}$, consumption and degradation in situ; E, exportation; S, stocked in the matte 
Acknowledgements. This work was supported by EEC grants EV4V-0139-B and STEP-0063-C. Field work was carried out at Ischia, where laboratory and diving facilities were kindly provided by Dr Lucia Mazzella and her staff at the Laboratorio di Ecologia del Benthos (Stazione Zoologica di Napoli).

\section{LITERATURE CITED}

Bach, S., Thayer, G. W., Lacroix, M. W. (1986). Export of detritus from eelgrass (Zostera marina) beds near Beaufort, North Carolina, U.S.A. Mar. Ecol. Prog. Ser. 28: $265-278$

Bay, D. (1984). A field study of the growth dynamics and productivity of Posidonia oceanica (L.) Delile in Calvi Bay, Corsica. Aquat. Bot. 20: 43-64

Bedhomme, A. L., Thelin, I., Boudouresque, C. F. (1983). Mesure de la production primaire des feuilles de Posidonia oceanica: modification de la méthode de Zieman. Botanica mar. 26: 35-43

Bocock, K. L., Gilbert, O. J., Capstick, C. K., Turner, D. C. Ward, J. S., Woodman, M. J. (1960). Changes in leaf litter when placed on the surface of soils with contrasting humus types. J. Soil Sci. 11. 1-9

Boudouresque, C. F. (1986). Longevité des rhizomes de Posidonia oceanica. Trav. sci. Parc nat. rég. Rés. nat. Corse 2: $12-13$

Boudouresque, C. F., Thommeret, J., Thommeret, Y. (1980). Sur la découverte d'un bioconcrétionnement fossile intercalé dans l'herbier à Posidonia oceanica dans la baie de Calvi (Corse). Journées Etud. Systèm. Biogéogr. Médit. Comm. Int. Explor. Scient. Méditerr., Cagliari, p. 139-142

Brock, T. C. M., Boon, J. J., Paffen, B. G. P. (1985). The effects of the season and of water chemistry on the decomposition of Nymphea alba L; weight loss and pyrolysis mass spectrometry of the particulate matter. Aquat. Bot. 22: 197-229

Bulteel, P., Coulon, P., Jangoux, P. \& M. (1992). Densités de population des espèces dominantes d'échinodermes dans l'herbier de posidonies du Lacco Ameno (lle d'Ischia, Italie): observations préliminaires. In: Scalera-Liaci, L., Canicatti, C. (eds.) Echinoderm research 1991 Balkema, Rotterdam, p. 181-183

Colantoni, P., Gallignani, P., Fresi, E., Cinelli, F. (1982). Patterns of Posidonia oceanica (L.) Delile beds around the island of Ischia (Gulf of Naples) and adjacent waters. P.S.Z.N. I: Mar. Ecol. 3(1): 53-74

Dauby, P., Coulon, P. (1993). The actual food of macroconsumers grazing on leaves or ingesting detritus of Posidonia oceanica seagrasses: a $\delta^{13} \mathrm{C}$ study. Belg. J. Zool. 123 (Suppl. 1): 14-15

Delgado, O. (1986). Contenido de fosforo de los tejidos de fanerogamas marinas del Mediterraneo y su relacion con la dinamica de cada especie. Oecologia aquat. 8: 139-151

Fenchel, T. (1970). Studies on the decomposition of organic detritus derived from the turtle grass Thalassia testudinum. Limnol. Oceanogr. 15: 14-20

Fenchel, T. (1977). Aspects of the decomposition of seagrasses. In: Seagrass ecosystems, a scientific perspective. Mar. Sci. 4: 123-145

Francour, P. (1985). Root and rhizome biomass of Posidonia oceanica bed. Rapp. P.-v. Réun. Comm. int. Explor. scient. Méditerr. 29(5): 183-185

Francour, P. (1990). Dynamique de l'écosystème à Posidonia oceanica dans le Parc national de Port-Cros. Analyse des compartiments matte, litière, faune vagile, échinodermes et poissons. Doctorat d'Université, Univ. P. M. Curie, Paris

Francour, P., Semroud, R. (1992). Calculation of the root area index in Posidonia oceanica in the western Mediterranean. Aquat. Bot. 42: 281-286

Fry, B., Virnstein, R. W. (1988). Leaf production and export of the seagrass Syringodium filiforme Kutz. in Indian River Lagoon, Florida. Aquat Bot. 30: 261-266

Giraud, G. (1979). Sur une méthode de mesure et de coptage des structures foliaires de Posidonia oceanica (Linnaeus) Delile. Bull. Mus. Hist. nat. Marseille 39: 33-39

Godshalk, G. L., Wetzel, R. G. (1978). Decomposition of aquatic angiosperms. II. Particulate components. Aquat. Bot. 5: $301-327$

Greenway, M. (1974). The effects of cropping on the growth of Thalassia testudinum (Konig) in Jamaica. Aquaculture 4(2): 199-206

Greenway, M. (1976). The grazing of Thalassia testudinum in Kingston Harbour, Jamaica. Aquat. Bot., 2: 117-126

Harmelin-Vivien, M. L., Francour, P. (1992). Trawling or visual censuses? Methodological bias in the assessment of fish populations in seagrass beds. P.S.Z.N. I: Mar. Ecol. 3(1): 41-51

Hemminga, M. A., Harrison, P. G., Van Lent, F. A. (1991). The balance of nutrient losses and gains in seagrass meadows. Mar. Ecol. Prog. Ser. 71: 85-96

Hillman, K., Walker, D. I., Larkum, A. W. D., McComb, A. J (1989). Productivity and nutrient limitation. In: Larkum, A W. D., McComb, A. J., Shepherd, S. A. (eds.) Biology of seagrasses. Elsevier, Amsterdam, p. 635-685

Josselyn, M. N., Calliet, G. M., Niesen, T. M., Cowen, R., Hurley, A. C. Connor, J., Hawes, S. (1983). Composition, export and faunal utilization of drift vegetation in the Salt River submarine canyon. Estuar. coast. Shelf Sci. 17: 447-465

Josselyn, M. N., Fonseca, M., Niesen, T., Larson, R. (1986). Biomass, production and decomposition of a deepwater seagrass, Halophila decipiens Ostenfeld. Aquat. Bot. 25: 47-61

Libes, M. (1985). Contribution à l'étude de la production primaire des herbiers à Posidonia oceanica par la méthode du carbone 14 appliquée in situ. J. Rech. océanogr. 10(1): $24-28$

Mann, K. H. (1972). Macrophyte production and detritus food chains in coastal waters. Mem. Ist. Ital. Idrobiol. 29: $353-383$

Mateo, M. A., Sabate, S. (1989). Digestión de material vegetal por vía húmeda mediante métodos clásicos modificados y microondas comofuente de energía. Documentos de trabajo. Depto de Ecología, Facultad de Biología, Universidad de Barcelona

Mazzella, L., Scipione, M. B., Buia, M. C. (1989). Spatiotemporal distribution of algal and animal communities in a Posidonia oceanica Meadow. P.S.Z.N. I: Mar. Ecol. 10(2): $107-129$

McRoy, C. P. (1966). The standing stock and ecology of eelgrass, Zostera marina, in Izembek Lagoon, Alaska. M.Sc. thesis, Univ. of Washington, Seattle

McRoy, C. P., McMillan, C. (1977). Production, ecology and physiology of seagrasses. In: McRoy, C. P., Helfferich, C. (eds.) Seagrass ecosystems. Dekker, New York, p. 53-87

Molinier, R., Picard, J. (1952). Recherches sur les herbiers de Phanérogames marines du littoral méditerranéen français. Annls. Inst. océanogr., Paris 27(3): 157-234

Nienhuis, P. H., De Bree, B. H. H. (1980). Production and growth dynamics of eelgrass (Zostera marina) in brackish lake Grevelingen (The Netherlands). Neth. J. Sea Res. 14(1): $102-118$

Ogden, J. C. (1980). Faunal relationships in Caribbean seagrass beds. In: Phillips, R. C., McRoy, C. P. (eds.) Handbook of seagrass biology, an ecosystem perspective. Garland STPM Press, New York, p. 173-198 
Ott, J. A. (1980). Growth and production in Posidonia oceanica (L.) Delile. P.S.Z.N. I: Mar. Ecol. 1: 47-64

Ott, J. A. (1981). Adaptive strategies at the ecosystem level: examples from two benthic marine systems. P.S.Z.N. I: Mar. Ecol. 2(2): 113-158

Ott, J. A., Maurer, L. (1977). Strategies of energy transfer from marine macrophytes to consumer levels: the Posidonia oceanica example. In: Keegan, B. F., Ceidigh, P. O., Boaden, P. J. S. (eds.) Biology of benthic organisms. Pergamon Press, Oxford, p. 493-502

Parker, P. L., Gibbs, A., Lawler, R. (1963). Cobalt, iron and magnesium in a Texas bay. Publs. Inst. mar. Sci. Univ. Texas 1: $28-32$

Peres, J. M. (1953). Les formations détritiques infralittorales issues des herbiers de Posidonies. Rec. Trav. Stn mar. Endoume 9(4): 29-38

Pergent, G. (1990). Lepidochronological analysis in the seagrass Posidonia oceanica: a standardized approach. Aquat. Bot. 37: 39-54

Pergent, G., Pergent-Martini, C. (1988). Phénologie de Posidonia oceanjca (Linnaeus) Delile dans le bassin méditerranéen. Annls. Inst. océanogr., Paris 64(2): 79-100

Pergent, G., Pergent-Martini, C. (1990). Some appications of lepidochronological analysis in the seagrass Posidonia oceanica. Botanica mar. 33: 299-310

Pergent G., Pergent-Martini, C. (1991). Leaf renewal cycle and primary production of Posidonia oceanica in the bay of Lacco Ameno (Ischia, Italy) using lepidochronological analysis. Aquat. Bot. 42:49-66

Pergent-Martini, C., Pergent, G., Romero, J. (1990). Standard procedure for the study of Posidonia oceanica leaf litter. Rapp. P.-v. Réun. Comm. int. Explor. scient. Méditerr. 32(1) B-19: 7

Picard, J. (1965). Importance, répartition et rôle du matériel organique végétal issu des prairies de Posidonies. Rapp. P.-v. Réun. Comm. int. scient. Méditerr. 18(1): 91-92

Pirc, H. (1983). Belowground biomass of Posidonia oceanica (L.) Delile and its importance to the growth dynamics. In: Int. Symp. Aquat. Macrophytes, Nijmegen, p. 177-181

This article was submitted to the editor
Romero, J. (1989). Primary production of Posidonia oceanica beds in the Medas Islands (Girona, NE Spain\}. In: Boudouresque, C. F., Meinesz, A., Fresi, E., Gravez, V. (eds.) International Workshop on Posidonia oceanica Beds, Vol. 2. GIS Posidonie, Marseilles, p. 85-91

Romero, J., Pergent, G., Pergent-Martini, C., Mateo, M. A., Regnier, C. (1992). The detritic compartment in a Posidonia oceanica meadow: litter features, decomposition rates, and mineral stocks. P.S.Z.N. I: Mar. Ecol. 13(1): 69-83

Sand-Jensen, K. (1975). Biomass, net production and growth dynamics in an eelgrass (Zostera marina L.) population in Vellerup Vig, Denmark. Ophelia 14: 185-201

Semroud, R., Benkorteby, N., Tamouza, F. Z. (1990). Phénologie de Posidonia oceanica dans la région d'Alger (Algérie): données préliminaires sur la biométrie foliaire. Rapp. P.-v. Réun. Comm. int. Explor. scient. Méditerr. 32(1) B-I16: 10

Thayer, G. W., Bjørndal, K. A., Ogden, J. C., Williams, S. L., Zieman, J. C. (1984). Role of larger herbivores in seagrass communities. Estuaries $7(4 \mathrm{~A}): 351-376$

Thelin, I., Giorgi, J. (1984). Production de feuilles dans un herbier superficiel à Posidonia oceanica, évaluée par une méthode dérivée de là méthode de Zieman. In: Boudouresque, C. F., Jeudy de Grissac et Olivier, J. (eds.) International Workshop on Posidonia oceanica Beds, Vol. 2 GIS Posidonie, Marseilles, p. 271-276

Verlaque, M., Nedelec, H. (1983). Note preliminaire sur les relations biotiques Paracentrotus lividus (LMK.) et herbier de Posidonies. Rapp. P.-v. Réun. Comm. int. Explor scient. Méditerr. 28(3): 157-158

Wittmann, K., Mazzella, L., Fresi, E. (1981). Age specific patterns of leaf growth: their determination and importance for epiphytic colonization in Posidonia oceanica (L.) Delile. Rapp. P.-v. Réun. Comm. int. Explor. scient. Méditerr. 27: 189-191

Zieman, J. C., Thayer, G. W., Robblee, M. B., Zieman, R. T. (1979). Production and export of seagrasses from a tropical bay. In: Livingston, R. J. (ed.) Ecological processes in coastal and marine systems. Plenum Press, New York, p. 21-34

Manuscript first received: October 4, 1993

Revised version accepted: November 24, 1993 